\title{
Efforts to Improve the Performance of Posyandu Cadres Based on Analysis of Cadre Empowerment in Tulungagung Regency, Indonesia
}

\author{
Farida Handayani ${ }^{1}$, Ratna Dwi Wulandari², Agung Dwi Laksono ${ }^{3}$ \\ ${ }^{I}$ Master Program in Health Policy and Administration, Faculty of Public Health, Universitas Airlangga, Indonesia, \\ ${ }^{2}$ Researcher, Department of Health Policy and Administration, Faculty of Public Health. Universitas Airlangga, \\ Indonesia, ${ }^{3}$ Researcher, National Institute of Health Research and Development, Indonesian Ministry of Health.
}

\begin{abstract}
Posyandu is one form of Community-Based Health Efforts held together with the community in obtaining basic health services. The cadre's role is to provide health information to the community, as a community mobilizer to come to Posyandu and a motivator to realize maternal and child health. The research was aimed at developing an effort to improve the performance of Posyandu cadres based on an analysis of empowerment in Tulungagung Regency. The study was conducted using observational analytic method with a sample of 32 Posyandu. The study was conducted in Tulungagung Regency in January-March 2020. The results showed that there was a relationship between the process of empowering and capability empowerment with the performance of Posyandu cadres $(0.019 ; 0.001)$. There was a relationship between cadre training and alignment $(0.002)$; the relationship between the availability of facilities and the role of the village with capability $(0.042 ; 0.028)$ and the relationship between the development of cadres and trusts $(0.028)$. It could be concluded that the performance of Posyandu cadres was influenced by the process of empowering alignment and capability. While trust was not related to the performance of Posyandu cadres. The process of empowering alignment was influenced by cadre training; capability was influenced by the availability of facilities and the role of villages.
\end{abstract}

Keywords: Posyandu,cadre performance, empowerment.

\section{Introduction}

One of the 2015-2020 Sustainable Development Goals (SDGs) goals is to end hunger, including overcoming malnutrition ${ }^{1}$. Achieving these targets through health efforts and community empowerment, including Posyandu (Pos Pelayanan Terpadu/Integrated Service Posts) ${ }^{2}$. Posyandu is one form of CommunityBased Health Efforts (CBHE) which is held together with the community in obtaining basic health services.

\footnotetext{
Corresponding Author:

Ratna Dwi Wulandari

Faculty of Public Health Universitas Airlangga, Indonesia

e-mail: ratna-d-w@fkm.unair.ac.id
}

Posyandu activities consist of maternal and child health services, family planning, immunization, nutrition, prevention, and prevention of diarrhea. One of the benefits of Posyandu for the community is that the growth of children under five is monitored so that it improves the health status of the community ${ }^{3}$. Early detection of nutritional cases can be done by weighing toddlers. This is intended if the child's weight does not rise, recovery and prevention efforts can be made immediately, so as not to become malnourished. Handling according to the management of nutritional cases will reduce the risk of death so that mortality due to malnutrition can be suppressed ${ }^{4}$.

Cadres have a large role in the smooth running of Posyandu activities. The task of planning various activities that exist in the Posyandu, implementing, evaluating, and controlling Posyandu activities, and 
reporting on Posyandu activities is carried out by cadres ${ }^{3}$. The role of cadres as providers of health information to the community, community mobilizers to come to Posyandu, and motivators to help realize maternal and child health ${ }^{5}$. Looking at the Posyandu cadre's tasks, it can be concluded that the Posyandu will be implemented optimally if the Posyandu cadre's performance is good.

Empowerment cadres for Posyandu for Toddler can be studied with an empowerment approach consisting of Alignment, Capability, Trust, and Participation, adapted from the theory of Tenner and Detoro in 1992 in Total Quality Management (TQM) ${ }^{6}$. The results of several studies indicate that community participation in Posyandu is influenced by cadre performance as a dominant factor and availability of facilities ${ }^{7}$. There is a link between Posyandu cadre guidance and trust, capacity with Posyandu cadre participation, education, and mother's work with the presence of toddlers in Posyandu ${ }^{8}$.

According to data from the Tulungagung Regency Health Office, in 2018, there were 27 Health Center out of 32 Health Center (84.4\%). If seen from the total achievement of recording-reporting indicators, the community participation in Posyandu has not yet reached the $80.0 \%$ target $^{9}$. Not yet achieved community participation in Posyandu or the arrival coverage of $74.7 \%$ of the $80.0 \%$ target in Tulungagung Regency in 2018 , is likely due to the performance of Posyandu cadres and toddlers factors. ew policies and commitments for implementation are needed to produce positive results ${ }^{10}$. The research study focused on factors that influence the performance of Posyandu cadres in achieving community participation in Posyandu. This study aims to compile efforts to improve the performance of Posyandu cadres based on an analysis of Posyandu cadre empowerment in Tulungagung Regency.

\section{Materials and Method}

The study was conducted for 3 months, namely from January to March 2020 in the Work Area of the Tulungagung Regency Health Office. This study uses a cross-sectional approach. The instrument used in this study was a questionnaire. The population in this study were Posyandu cadres and mothers of toddlers with a large sample of 32 Posyandu. The research sample was taken using multistage random sampling.

Primary data was taken through a Likert scale questionnaire. Data were analyzed descriptively and using the Spearman Correlation test. The scientific discussion is held to produce recommendations on the emergence of strategic issues.

Findings: The results showed that the availability of adequate category facilities was $71.9 \%$, and the development of Posyandu cadres in the category was sufficient $24.0 \%$. The availability of Posyandu facilities is: weigh tools, length/height measurements, extension media, register books. While the efforts to develop Posyandu cadres are related to the improvement of Posyandu functions and performance. The guidance covers aspects of the program, institutional, and power aspects ${ }^{3}$. The results showed that the role of the village category was $68.8 \%$. The village is responsible for providing policy support, facilities, and funds; coordinating community mobilization to attend Posyandu; coordinating cadres, Posyandu administrators, and community leaders; following up on Posyandu results; Posyandu training ${ }^{3}$.

The results showed that cadres had received $62.5 \%$ training. Posyandu cadre training aims to create quality Posyandu cadres. Training is to improve skills so that cadres can participate as Posyandu managers. Posyandu cadre training is expected to improve cadre performance ${ }^{11}$. The results showed that the alignment of the good category was $65.6 \%$, the capability of the good category was $75.0 \%$, and the trust of the good category was $68.8 \%$. Alignment is the stage of convincing employees to understand their vision, mission, values, policies, goals, and method. Capability is the stage of building employee capacity that is increasing the knowledge, abilities, and skills of each individual and the availability of resources, method, and technology to build systems. While trust is the stage of superiors trust in subordinates raises employee confidence to do work.

The results showed that the performance of Posyandu cadres in the good category was $84.4 \%$. The performance of Posyandu cadres is cadres carrying out their duties, both before, during, and after the opening of Posyandu, namely: disseminating information about Posyandu opening days; register; child health services (the measurement of body weight, height, head circumference of children, monitoring of immunization status of children); recording of measurement results; counseling; make home visits; provide counseling; holding discussions with mothers of toddlers; learn Posyandu Information System. 
Relationship between Training and Alignment: The results of the analysis of the relationship between training and alignment can be seen in Table 1 . Table 1 shows that the training, tested by Spearman Correlation with alignment, obtained Sig. (2-tailed) $=0.002$ which means there is a relationship between training and alignment. Increased knowledge and skills of cadres are influenced by training so that cadres can manage Posyandu according to their competencies. This is in line with the results of research on training related to increasing cadre knowledge ${ }^{12}$.

Table 1. Relationship between Training and Alignment in Tulungagung Regency, Indonesia, 2020

\begin{tabular}{|c|c|c|c|c|c|c|c|}
\hline \multirow{3}{*}{ No } & \multirow{3}{*}{ Training } & \multicolumn{4}{|c|}{ Alignment } & \multirow{2}{*}{\multicolumn{2}{|c|}{ Total }} \\
\hline & & \multicolumn{2}{|c|}{ Enough } & \multicolumn{2}{|c|}{ Good } & & \\
\hline & & $n$ & $\%$ & $\mathrm{n}$ & $\%$ & $\mathrm{n}$ & $\%$ \\
\hline 1 & Never & 8 & 66.7 & 4 & 33.3 & 12 & 100.0 \\
\hline 2 & Ever & 3 & 15.0 & 17 & 85.0 & 20 & 100.0 \\
\hline & Total & 11 & 34.4 & 21 & 65.6 & 32 & 100.0 \\
\hline
\end{tabular}

Relationship between Availability of Facilities and Capability: The results of the analysis of the relationship between the availability of facilities and capability can be seen in Table 2 . Table 2 shows that the availability of facilities, tested by Spearman Correlation with capability, obtained Sig. (2-tailed) $=0.042$ which means there is a relationship between facility support and capability. According to the results of interviews with respondents, counseling media (flip sheets, posters, leaflets) have been given much damage and missing. This is in line with research on the relationship between facilities and infrastructure and the practices of cadres in Posyandu, namely to improve the ability of cadres in Posyandu, the availability of facilities and infrastructure that supports ${ }^{13}$.

Table 2. Relationship between Availability of Facilities and Capability in Tulungagung Regency, Indonesia, 2020

\begin{tabular}{|c|c|c|c|c|c|c|c|}
\hline \multirow{3}{*}{ No } & \multirow{3}{*}{ Availability of Facilities } & \multicolumn{4}{|c|}{ Capability } & \multirow{2}{*}{\multicolumn{2}{|c|}{ Total }} \\
\hline & & \multicolumn{2}{|c|}{ Enough } & \multicolumn{2}{|c|}{ Good } & & \\
\hline & & $\mathbf{n}$ & $\%$ & n & $\%$ & n & $\%$ \\
\hline 1 & Enough & 8 & 34.8 & 15 & 65.2 & 23 & 100.0 \\
\hline 2 & Good & 0 & 0.0 & 9 & 100.0 & 9 & 100.0 \\
\hline & Total & 8 & 25.0 & 24 & 75.0 & 32 & 100.0 \\
\hline
\end{tabular}

Relationship between Village Roles and Capability: The results of the analysis of the relationship between the role of villages and capability can be seen in Table 3. Table 3 shows that the role of villages, tested by Spearman Correlation with capability, obtained Sig. $(2$-tailed $)=0.028$ which means there is a relationship between the role of the village with capability. This is in line with the results of research on the relationship between the village's role and the empowerment of Posyandu cadres, namely the Village Head's role in providing facilities, monitoring and supervising cadres' tasks, considering the ability of cadres before giving assignments, giving rewards, and developing Posyandu ${ }^{14}$. 
Table 3. Relationship between the Role of Villages with Capability in Tulungagung Regency 2020

\begin{tabular}{|c|c|c|c|c|c|c|c|}
\hline \multirow{3}{*}{ No } & \multirow{3}{*}{ The Role of Villages } & \multicolumn{4}{|c|}{ Capability } & \multirow{2}{*}{\multicolumn{2}{|c|}{ Total }} \\
\hline & & \multicolumn{2}{|c|}{ Enough } & \multicolumn{2}{|c|}{ Good } & & \\
\hline & & $\mathbf{n}$ & $\%$ & $\mathbf{n}$ & $\%$ & $\mathbf{n}$ & $\%$ \\
\hline 1 & Enough & 8 & 36.4 & 14 & 63.6 & 22 & 100.0 \\
\hline 2 & Good & 0 & 0.0 & 10 & 100.0 & 10 & 100.0 \\
\hline & Total & 8 & 25.0 & 24 & 75.0 & 32 & 100.0 \\
\hline
\end{tabular}

\section{Relationship between Posyandu Cadre} Development and Trust: The results of the analysis of the relationship between the development of Posyandu cadres and trust can be seen in Table 4 . Table 4 shows that the Posyandu cadre development, tested by Spearman Correlation with trust, obtained Sig. (2-tailed) $=0.028$ which means there is a relationship between the formation of Posyandu cadres with trust. Trust between the Health
Centerand cadres is well established with frequent cadre refreshing activities. The Health Center felt that cadres who often received coaching had been able to carry out their duties properly, resulting in trust. Cadres become more confident in carrying out their duties because they have won the trust of the Health Center. This research is in line with research that developing cadres can increase self-confidence in Posyandu cadres ${ }^{15}$.

Table 4. Relationship between Posyandu Cadre Development and Trust in Tulungagung Regency, Indonesia, 2020

\begin{tabular}{|c|c|c|c|c|c|c|c|}
\hline \multirow{3}{*}{ No } & \multirow{3}{*}{$\begin{array}{l}\text { Posyandu Cadre } \\
\text { Development }\end{array}$} & \multicolumn{4}{|c|}{ Trust } & \multirow{2}{*}{\multicolumn{2}{|c|}{ Total }} \\
\hline & & \multicolumn{2}{|c|}{ Enough } & \multicolumn{2}{|c|}{ Good } & & \\
\hline & & $\mathbf{n}$ & $\%$ & $\mathbf{n}$ & $\%$ & $\mathbf{n}$ & $\%$ \\
\hline 1 & Enough & 10 & 41.7 & 14 & 58.3 & 24 & 100.0 \\
\hline 2 & Good & 0 & 0.0 & 8 & 100.0 & 8 & 100.0 \\
\hline & Total & Total & 31.3 & 22 & 68.8 & 32 & 100.0 \\
\hline
\end{tabular}

Relationship between Alignment, Capability, Trust and Posyandu Cadre Performance: The results of the analysis of the relationship of alignment, Capability and Trust with the performance of Posyandu cadres can be seen in Table 5. Table 5 shows that the alignment was tested by Spearman Correlation with the performance of Posyandu cadres, obtained by Sig. (2-tailed) $=0.019$ which means there is a relationship between alignment and the performance of Posyandu cadres. A person's behavior is determined by a person's knowledge and attitude $^{16}$. This is consistent with research that Posyandu cadre knowledge is related to cadre participation ${ }^{17}$.

Table 5. Relationship of Alignment, Capability and Trust with Posyandu Cadre Performance in Tulungagung Regency, Indonesia, 2020

\begin{tabular}{|c|c|c|c|c|c|c|c|}
\hline \multirow{3}{*}{ No } & \multirow{3}{*}{ Alignment } & \multicolumn{4}{|c|}{ Posyandu Cadre Performance } & \multirow{2}{*}{\multicolumn{2}{|c|}{ Total }} \\
\hline & & \multicolumn{2}{|c|}{ Enough } & \multicolumn{2}{|c|}{ Good } & & \\
\hline & & $\mathbf{n}$ & $\%$ & $\mathbf{n}$ & $\%$ & $\mathbf{n}$ & $\%$ \\
\hline 1 & Enough & 4 & 12.5 & 7 & 21.9 & 22 & 100.0 \\
\hline 2 & Good & 1 & 3.1 & 20 & 62.5 & 10 & 100.0 \\
\hline & Total & 5 & 15.6 & 27 & 84.4 & 32 & 100.0 \\
\hline
\end{tabular}




\begin{tabular}{|c|c|c|c|c|c|c|c|}
\hline \multirow{3}{*}{ No } & \multirow{3}{*}{ Capability } & \multicolumn{4}{|c|}{ Posyandu Cadre Performance } & \multirow{2}{*}{\multicolumn{2}{|c|}{ Total }} \\
\hline & & \multicolumn{2}{|c|}{ Enough } & \multicolumn{2}{|c|}{ Good } & & \\
\hline & & $\mathbf{n}$ & $\%$ & $\mathbf{n}$ & $\%$ & $\mathbf{n}$ & $\%$ \\
\hline 1 & Enough & 4 & 50.0 & 4 & 50.0 & 8 & 100.0 \\
\hline 2 & Good & 1 & 4.2 & 23 & 95.8 & 24 & 100.0 \\
\hline \multicolumn{2}{|r|}{ Total } & 5 & 15.6 & 27 & 84.4 & 32 & 100.0 \\
\hline \multirow{3}{*}{ No } & \multirow{3}{*}{ Trust } & \multicolumn{4}{|c|}{ Posyandu Cadre Performance } & \multirow{2}{*}{\multicolumn{2}{|c|}{ Total }} \\
\hline & & \multicolumn{2}{|c|}{ Enough } & \multicolumn{2}{|c|}{ Good } & & \\
\hline & & $\mathbf{n}$ & $\%$ & n & $\%$ & $\mathbf{n}$ & $\%$ \\
\hline 1 & Enough & 2 & 20.0 & 8 & 80.0 & 10 & 100.0 \\
\hline 2 & Good & 3 & 13.6 & 19 & 86.4 & 22 & 100.0 \\
\hline & Total & 5 & 15.6 & 27 & 84.4 & 32 & 100.0 \\
\hline
\end{tabular}

Table 5 shows that the capability was tested by Spearman Correlation with Posyandu cadre performance, obtained by Sig. (2-tailed) $=0.001$ which means there is a relationship between capability and performance of Posyandu cadres. The procurement of facilities from the Health Center and villages should be able to support cadres to do their jobs properly. This capability is not yet maximal, possibly because cadre training is still not comprehensive. So that the soft skills of cadres are not honed and cause the cadre skills are still lacking. This is consistent with research that cadre competencies, especially in the competency of cadre knowledge, attitudes and skills related to cadre performance ${ }^{18}$ and research on the availability of facilities related to cadre performance $^{19}$.

Table 5 shows that trust was tested by Spearman Correlation with the performance of Posyandu cadres, obtained by Sig. (2-tailed) $=0.658$ means there is no relationship between trust and the performance of Posyandu cadres. Trust in this case is the mutual trust between the Health Center and the village with cadres. Overall cadre trusts are in a good category $(68.8 \%)$. Tenner and Detoro stated that the trust of superiors can lead to the confidence of employees to carry out responsibilities so that the commitment to contribute to the maximum ${ }^{6}$.

\section{Conclusions}

The better the process of empowering alignment and capability, the better the performance of Posyandu cadres. The alignment empowerment process is in line with the increasing frequency of Posyandu cadre training. The process of empowering capability will be better if the availability of facilities is more complete and the role of the village is getting better. Meanwhile, cadre trusts will be better if Posyandu cadre guidance is also increasing in quality and quantity. Various ways can be done by several parties to help in improving cadre performance by increasing factors related to cadre performance.

Acknowledgments: The author would like to thank Universitas Airlangga, which has allowed completing this final project.

Source of Funding: Self-funding

\section{Conflict of Interests: Nil}

Ethical Clearance: The study has passed the ethical test from the Ethics Commission of the Faculty of Nursing, Universitas Airlangga (EC Number: 1936KEPK). The respondents' identities have all been deleted from the dataset. Respondents have provided written approval for their involvement in the study.

\section{References}

1. Hoelman MB, Parhusip BTP, Eko S, Bahagijo S, Santono H. Sustainable Development GoalsSDGs: Panduan Untuk Pemerintah Daerah (Kota dan Kabupaten) dan Pemangku Kepentingan Daerah [Internet]. Jakarta: International NGO Forum on Indonesian Development (INFID); 2016. Available from: https://www.infid.org/wp-content/ uploads/2018/07/Buku-Panduan-SDGs-untukPemda.pdf 
2. Kementerian Kesehatan RI. Peraturan Menteri Kesehatan Nomor 39 Tahun 2016 tentang Pedoman Penyelenggaraan PIS - PK (Program Indonesia Sehat dengan Pendekatan Keluarga) [Internet]. Indonesia; 2016. Available from: https://www.academia.edu/31827720/Permenkes_ PMK_No._39_tahun_2016_tentang_Pedoman Penyelenggaraan_PIS_-_PK_Program_Indonesia_ Sehat_Dengan_pendekatan_Keluarga.pdf

3. Sekretariat Jenderal Kementerian Kesehatan RI. Pedoman Umum Pengelolaan Posyandu [Internet]. Jakarta: Kementerian Kesehatan Republik Indonesia; 2011. 1-60 p. Available from: http://promkes.kemkes.go.id/pedoman-umumpengelolaan-posyandu

4. Kementerian Kesehatan RI. Profil Kesehatan Indonesia. Jakarta; 2018.

5. Kementerian Kesehatan RI. Buku Saku Posyandu. Jakarta; 2012.

6. Supriyanto S, Wulandari RD. Manajemen Mutu Pelayanan Kesehatan. Surabaya: Health Advocacy; 2011.

7. Nasution, Zulihartika W. Faktor-Faktor yang Mempengaruhi Pemanfaatan Posyandu Balita di Wilayah Kerja Puskesmas Sayur Matinggi Kabupaten Tapanuli Selatan Tahun 2018. Medan; 2018. p. 156.

8. Putri AM. Upaya Peningkatan Cakupan Penimbangan Balita (D/S) berdasarkan analisis faktor balita dan Pemberdayaan Kader. Surabaya; 2014.

9. Dinas Kesehatan Kabupaten Tulungagung. Profil Kesehatan Kabupaten Tulungagung. Tulungagung; 2018.

10. Wulandari RD, Supriyanto S, Bagus Qomaruddin M, Damayanti NA, Laksono AD. Change commitment and change efficacy of public health center in indonesia in implementing efforts to improve the quality of health services. Indian $\mathrm{J}$ Public Heal Res Dev. 2019;10(10):1923-8.

11. Kementerian Kesehatan RI. Kurikulum dan Modul Pelatihan Kader Posyandu. 2012.

12. Chahyanto BA. Pemberian Informasi Dasar Posyandu Melalui Kegiatan Penyegaran Kader Dalam Meningkatkan Pengetahuan Kader di Puskesmas Pelabuhan Sambas Kota SIBOLGA. Aceh Nutr. 2019;4 nomor 1:7-14.

13. Pangestuti NA. Beberapa Faktor yang Berhubungan Dengan Praktik Kader Dalam Penyuluhan di Meja 4 pada Posyandu di Kelurahan Ngaliyan, Kota Semarang. J Kesehat Masy. 2016;4 nomor 5.

14. Profita AC. Beberapa faktor yang berhubungan dengan keaktifan kader posyandu di Desa Pengadegan Kabupaten Banyumas. J Adm Kesehat Indones. 2018;6 nomor 2.

15. Rahman LOA. Pendampingan Sistem Informasi Posyandu (SIP) Terinteragi Meningkatkan Efikasi Diri. J Publ Kebidanan YKPP. 2019; Volume 10.

16. Notoatmodjo S. Pendidikan dan Perilaku Kesehatan. Rineka Cipta; 2003.

17. Lukwan. Kontribusi Pengetahuan Kader Terhadap Kinerja Kader Posyandu di Puskesmas Matandahi Konawe Utara. J Penelit dan Pengemb Pelayanan Kesehat. 2018;2 nomor 1.

18. Hastuti D. Pengaruh motivasi, kompetensi dan kepuasan terhadap kinerja kader kesehatan dengan komitmen kerja sebagai variabel intervening (Studi Puskesmas Pagiyanten Kabupaten Tegal). J Magisma. 2018;6 nomor 1.

19. Kartika. Faktor yang mempengaruhi peran kader dalam upaya perbaikan gizi balita di wilayah kerja Puskesmas Mila. J Kesehat Glob. 2018;1 nomor 2:45-52. 